\title{
Program Pendidikan Lingkungan Hidup Melalui Kegiatan Duta Lingkungan Hidup di Sekolah Menengah Atas
}

\author{
Bayu Widiyanto, Retna Kusuma Astuti, Yuni Arfiani \\ Program Studi Pendidikan IPA FKIP \\ Universitas Pancasakti Tegal \\ E-mail : bayuwidiyanto@gmail.com
}

DOI: http://dx.doi.org/10.21107/pgd.v5i1.5166

\begin{abstract}
Artikel Diterima : 10 November 2018/ Revisi : 17 Februari 2019/Terbit : 15 April 2019
Abstrak

Permasalahan lingkungan timbul karena kecerobohan manusia dalam pengelolaan lingkungan hidup. Kepedulian individu terhadap kelestarian lingkungan hidup sangat dipengaruhi oleh budaya dan pendidikan tentang lingkungan hidup (PLH) yang diajarkan pada tiap negara atau daerah masingmasing. Implemetasi PLH harus diwujudkan dalam suatu program yang dapat menggerakkan masa, dan juga terdapat penghargaan bagi yang berprestasi dalam bidang lingkungan hidup. Salah satunya dengan serangkaian kegiatan Duta Lingkungan Hidup. Duta Lingkungan Hidup Sekolah (Green Student) merupakan perwakilan individu terpilih pada suatu lembaga (sekolah) atau wilayah pemerintahan yang memiliki pengetahuan dan berperan aktif dalam bidang lingkungan hidup dan diharapkan mampu mengajak dan membangun komunitas yang peduli terhadap kelestarian lingkungan hidup. Kegiatan Duta Lingkungan Hidup dilaksanakan dalam 3 Tahap, tahap I merupakan tes kemampuan kognitif, tahap II merupakan uji kreativitas (membuat produk daur ulang) atau uji ide/ gagasan dalam memecahkan permasalahan lingkungan, sedangkan tahap III merupakan tahap orasi ilmiah. Pemilihan Duta Lingkungan Hidup Kabupaten Tegal diikuti oleh 80 peserta, sedangkan di Kabupaten Brebes diikuti oleh 71 peserta. Di akhir kegiatan telah terpilih Duta Lingkungan Hidup I, II, dan II untuk Kabupaten Brebes dan Kabupaten Tegal. Selain itu terpilih juga Duta Lingkungan Hidup Favorit yang penilaiannya didasarkan atas keunikan kostum saat pelaksanaan kampanye Go Green
\end{abstract}

Kata Kunci : duta lingkungan hidup, pengelolaan lingkungan, Kabupaten Brebes

\section{PENDAHULUAN}

Pendidikan Lingkungan Hidup (PLH) merupakan salah satu upaya yang dikembangkan oleh masyarakat dunia untuk mengoptimalkan peran masyarakat dalam mengatasi permasalahan lingkungan. Pengertian PLH sendiri dapat diartikan sebagai upaya mengubah perilaku dan sikap yang dilakukan oleh berbagai pihak atau elemen masyarakat yang bertujuan untuk meningkatkan pengetahuan, keterampilan dan kesadaran masyarakat tentang nilai-nilai lingkungan dan isu permasalahan lingkungan yang pada akhirnya dapat menggerakkan masyarakat untuk berperan aktif dalam upaya pelestarian dan keselamatan lingkungan untuk kepentingan generasi sekarang dan yang akan datang. Pendidikan lingkungan hidup mempelajari permasalahan lingkungan khususnya masalah dan pengelolaan pencemaran, kerusakan lingkungan serta sumber daya dan konservasi (Tim MKU PLH Unnes, 2014).

Aspek penting yang diterapkan dalam pembelajaran PLH adalah kognitif dan afektif. Aspek kognitif meliputi proses pemahaman, dan menjaga keseimbangan aspek-aspek yang lain. Materi PLH harus diberikan sebagai materi yang harus diketahui dan dipahami oleh siswa, selanjutnya dikembangkan sendiri oleh siswa. Aspek afektif yang dapat diterapkan dalam PLH meliputi tingkah laku, nilai dan komitmen yang diperlukan untuk membangun masyarakat yang berkelanjutan (sustainable).

Rendahnya sikap dan kepedulian siswa terhadap lingkungan tentu memprihatinkan, karena melalui pendidikan di sekolah semestinya sikap dan perilaku peduli terhadap lingkungan hidup telah ditanamkan. Kenyataannya, meskipun pelajaran Ilmu Pengetahuan Alam (IPA) sudah diberikan sejak Sekolah Dasar, tetapi belum mampu membekali siswa dengan pengetahuan dan sikap peduli terhadap lingkungan. Untuk dapat mengajarkan pendidikan lingkungan dan menanamkan sikap peduli lingkungan kepada siswa, guru perlu meningkatkan pengetahuannya tentang pendidikan lingkungan dan cara menanamkan sikap peduli lingkungan (Amini dan Munandar, 2010). 
Beberapa isu penting dalam masalah lingkungan yang sering ditemui di lingkungan masyarakat Indonesia, khususnya Kabupaten Tegal dan Kabupaten Brebes adalah masalah persampahan. Peningkatan volume sampah berkembang secara eksponensial sejalan dengan perkembangan jumlah penduduk dan peningkatan aktivitas pembangunan yang belum dibarengi dengan pengelolaan sampah kota. Sampah akan menjadi beban bumi, artinya ada risiko-risiko yang akan ditimbulkannya (Hadi, 2000). Berdasarkan data dari Rencana Pembangunan Jangka Panjang Daerah Kabupaten Tegal tahun 2005-2025, Produksi sampah pada tahun 2004 rata-rata sebanyak $345 \mathrm{~m} 3 /$ hari, dengan sampah yang terangkat atau tertangani sebanyak $248,81 \mathrm{~m} 3 /$ hari $(72,12$ $\%)$. Sebagian besar produksi sampah berasal dari sampah pasar (142,47 m3/hari) dan permukiman $(108,90 \mathrm{~m} 3 /$ hari). Dari volume sampah tersebut. $46,20 \%$ merupakan sampah organik dan 34,15 $\%$ merupakan sampah berupa karet atau plastik. Produksi sampah ini akan terus meningkat jumlahnya seiring dengan semakin bertambah banyaknya penduduk.

Kabupaten Tegal terdiri dari 18 Kecamatan. Secara geografis kabupaten Tegal memiliki bentang alam dari laut sampai pegunungan. Di bagian hulu (wilayah selatan) masih banyak dijumpai kawasan Hutan tepatnya daerah Gunung Slamet yang merupakan kawasan lindung sebagai daerah penyangga.Namun di bagian hilir terutama kota masih kurang akan penghijauan. Kondisi ini mengakibatkan wilayah bagian utara memiliki suhu udara yang panas. Kondisi sungai pun hampir selalu ditemukan adanya sampah plastik, karena masyarakatnya masih membuang limbah rumah tangga secara sembarangan. Kegiatan industri pun turut andil dalam mencemari lingkungan, mulai dari pencemaran limbah tahu sampai dengan pencemaran logam berat dari home industri pengecoran logam.

Kabupaten Brebes memiliki luas wilayah administrasi sebesar 166.297 Ha. Secara administrasi, Kabupaten Brebes terbagi dalam 17 kecamatan dan 297 desa/kelurahan. Kondisi lingkungan hidup (LH) di Kabupaten Brebes saat ini cenderung mengalami penurunan kualitas. Berbagai tindakan manusia yang tidak ramah lingkungan menyebabkan kerusakan-kerusakan yang akhirnya menjadi salah satu ancaman bagi masyarakat. Seperti kerusakan hutan akibat penebangan liar, pembuangan limbah sembarangan atau penambangan galian $\mathrm{C}$ tanpa izin, dan perubahan fungsi lahan pertanian. Masyarakat Brebes juga masih ada yang menebang pohon di daerah hulu dan membangun rumah pada lereng kemiringan lebih dari 450, akibatnya terjadi bencana longsor pada tebing terjal dan banjir pada hilir sungai. Lemahnya penegakan hukum lingkungan dan ringannya sanksi bagi pelanggar mengakibatkan sulitnya usaha pelestarian lingkungan (KLH Kab. Brebes, 2008).

Berdasarkan permasalahan yang disebutkan sebelumnya, menandakan bahwa kepedulian masyarakat Kab. Tegal dan Kab. Brebes untuk menjaga lingkungan masih kurang. Oleh karena itu setiap orang harus dibekali pendidikan lingkungan hidup (PLH) agar lebih peduli terhadap lingkungan. Penekanan pembelajaran PLH bukan hanya pada ranah teori tetapi harus dilibatkan secara aktif dalam praktek yang dapat mengubah sikap dan pola pikir masyarakat agar lebih peduli terhadap masalah lingkungan. Pelaksanaan PLH juga dapat dilaksanakan di luar sekolah dengan melibatkan masyarakat dan instansi negeri atau swasta. Implemetasi PLH harus diwujudkan dalam suatu program yang dapat menggerakkan masa, dan juga terdapat penghargaan bagi yang berprestasi dalam bidang lingkungan hidup. Salah satunya dengan serangkaian kegiatan Duta Lingkungan Hidup.

Duta Lingkungan Hidup (Green Ambassador) merupakan perwakilan individu terpilih pada suatu lembaga atau wilayah pemerintahan yang memiliki pengetahuan dan berperan aktif dalam bidang lingkungan hidup dan diharapkan mampu mengajak dan membangun komunitas / masyarakat yang peduli terhadap kelestarian lingkungan hidup. Duta Lingkungan hadir dalam perannya sebagai garis depan yang secara garis besar bertugas untuk menyuarakan gagasan tentang lingkungan pada masyarakat luas.

Tugas-tugas duta lingkungan yang akan dilaksanakan diantaranya: (1) Menyosialisasikan dan memberi informasi berbagai isu lingkungan, baik secara lisan (oral) maupun tertulis. Pengemasan gaya sosialisasi juga dapat dipersiapkan menjadi lebih atraktif dan menarik bergantung pada bagaimana cara setiap duta lingkungan untuk mensosialisasikan materi serta kondisi masyarakat sebagai sasaran; (2) Memotivasi setiap individu mengenai isu lingkungan. Duta Lingkungan merupakan seorang motivator lingkungan yang menjadi layaknya psikolog dengan kerja dan fungsi seperti orator; (3) Menjadi pencetus atau 
perintis berbagai isu lingkungan. Dibutuhkan seorang duta lingkungan yang bisa menjadi pencetus gagasan-gagasan baru dalam kapasitasnya sebagai duta pada bidang lingkungan hidup. Dalam berbagai program maupun gagasan yang muncul, perlu adanya aksi nyata untuk membuat gagasan tersebut menjadi lebih bermanfaat tak hanya sekadar menginspirasi, namun yang lebih utama adalah mampu memberi efek perubahan terhadap pola perilaku yang lebih memiliki karakter khususnya mengenai lingkungan hidup. Melalui Duta lingkungan dan serangkaian kegiatannya diharapkan dapat mewakili dan menyebarkan semangat dalam melestarikan lingkungan hidup kepada warga sekolah pada khususnya dan kepada masyarakat yang lebih luas

\section{METODE}

Pelaksanaan kegiatan IbM ini menggunakan metode Transfer of Knowledge yang merupakan penciptaan nilai nilai, dan menghasilkan keunggulan kompetitif yang berkesinambungan dengan mengoptimalkan proses komunikasi dan aplikatif sistem pengetahuan (Sangkala, 2007). Khalayak sasaran pada pengabdian ini meliputi panitia dan peserta kegiatan Duta Lingkungan Hidup. Panitia kegiatan ini sebagian dari mitra IbM yaitu pegawai BLH dan sebagian lagi dari pihak Universitas (Dosen dan Mahasiswa) yang akan mendampingi dalam serangkaian kegiatan DLH. Peserta kegiatan DLH ini meliputi siswa dan siswi perwakilan Duta Lingkungan Hidup dengan batasan tingkat $X$ atau XI SMA, SMK, dan MA se- Kabupaten atau Kota. Setiap sekolah hanya mengirimkan satu putra dan satu putri perwakilan DLH tingkat sekolah.

Kegiatan pengabdian masyarakat ini melalui beberapa tahapan yaitu: (1) koordinasi dengan BLH; (2) Pembuatan portal web duta lingkungan hidup; (3) Sosialisasi dan pendaftaran kegiatan; (4) Pembekalan materi lingkungan hidup; (5) Seleksi / pemilihan Duta Lingkungan Hidup; (6) Kegiatan Bhakti Lingkungan; dan (7) Sosialisasi hasil kegiatan para duta lingkungan hidup ke sekolah masing-masing. Tahap Koordinasi dimaksudkan agar adanya transfer ide dan gagasan akan pentingnya pendidikan lingkungan hidup melalui kegiatan Duta Lingkungan Hidup, sekaligus membahas segala persiapannya. Persiapan yang dilakukan antara lain: (1) pembentukan panitia dan deskripsi tugasnya; (2) perencanaan jadwal kegiatan dan strategi pelaksanaannya; (3) Pembuatan materi dan soal seleksi; dan (4) persiapan kebutuhan peralatan. Tahap selanjutnya yaitu pembuatan portal web, dimaksudkan sebagai media informasi seputar Pendidikan Lingkungan Hidup (PLH) dan sebagai media komunikasi kegiatan Duta Lingkungan Hidup. Informasi PLH meliputi; contoh kasus pencemaran lingkungan baik pada skala lokal, nasional ataupun internasional; pola hidup ramah lingkungan; teknologi ramah lingkungan seperti penggunaan energi baru terbarukan; sampai kebijakan pro lingkungan. Portal web Duta Lingkungan Hidup dimaksudkan sebagai media komunikasi kegiatan Duta Lingkungan Hidup mulai dari cara pendaftaran; jadwal seleksi; hasil seleksi dan agenda kegiatan Duta Lingkungan Hidup.

Pembekalan materi lingkungan hidup bertujuan untuk menambah wawasan dan pengetahuan peserta akan pentingnya PLH sebagai upaya menambah rasa kepedulian terhadap permasalahan lingkungan hidup. Metode yang digunakan bisa berupa ceramah, pemutaran video, atau demonstrasi misalnya cara daur ulang limbah. Materi lingkungan hidup juga harus dirumuskan dalam bentuk makalah persuasif yang mengajak pembaca atau audience agar menjalankan pola hidup ramah lingkungan dalam kehidupan sehari-hari. Makalah tersebut dibagikan pada tiap peserta DLH yang nantinya mereka harus mensosialisasikan ke sekolah mereka masing-masing.

Pemilihan Duta Lingkungan Hidup dimaksudkan menyeleksi peserta untuk dipilih sebagai juara 1 putra dan 1 putri Duta Lingkungan Hidup tingkat Kabupaten. Seleksi DLH dilakukan dengan beberapa tahap antara lain:

1. Tahap I: uji Pengetahuan tentang Lingkungan Hidup (60 Soal pilihan ganda).

2. Tahap II : meliputi 2 uji / test (a) Penulisan essay (langsung di tempat) dengan memilih tema yang di sudah ditentukan; (b) Presentasi atau demonstrasi uji kreasi pengolahan limbah/pengalaman di bidang PPLH.

3. Tahap III : orasi ilmiah di depan publik dengan memilih tema yang sudah ditentukan mengenai isu-isu lingkungan hidup.

Penentuan jumlah nominasi peserta tiap tahap dapat ditentukan sesuai kesepakatan atau mengikuti aturan berikut:

- Tahap I: diambil 15 besar putra dan putri (50 orang).

- Tahap II : diambil 5 besar putra dan putri (10 orang). 
- Tahap III : diambil juara $1,2,3$ putra dan putri (6 orang)

Kegiatan Duta Lingkungan Hidup bukan hanya sekedar pemilihan, akan tetapi yang terpenting adalah kegiatan aksi nyata memalui Bhakti Lingkungan. Kegiatan ini meliputi; kampanye "Go Green" (menggunakan banner/ poster dan membagi stiker Go Green); bersihbersih pantai atau sungai; dan penanaman pohon. Waktu pelaksanaan kampanye dan kegiatan bersih-bersih bisa dilakukan saat bertepatan dengan hari lingkungan hidup (5 Juni); hari bumi (22 April) atau bebas sesuai jadwal yang ditentukan, namun untuk penanaman pohon sebaiknya dilakukan pada awal musim penghujan yaitu pada bulan Oktober sampai November.

Tahapan evaluasi dilakukan dengan metode; survei dan wawancara kepada para siswa-siswi peserta DLH; dan pengisian kuesioner kepada panitia dari mitra IbM dalam hal ini pegawai BLH. Survei dan wawancara kepada siswa-siswi peserta DLH dimaksudkan untuk mengukur peningkatan pemahaman dan keterampilan seputar pendidikan lingkungan hidup, selain itu juga mendapatkan opini berupa kesan dan saran selama kegiatan DLH. Sedangkan pengisian kuesioner kepada panitia dari mitra IbM dalam hal ini pegawai BLH dimaksudkan untuk menganalisis kekuatan, kekurangan, peluang dan hambatan (SWOT) dari program Duta Lingkungan Hidup.

\section{HASIL DAN PEMBAHASAN}

Kegiatan Duta Lingkungan Hidup di Kabupaten $\underline{\text { Tegal }}$

Serangkaian kegiatan IBM yang kami lakukan melibatkan banyak pihak, antara lain Dinas Lingkungan Hidup, Dinas Pendidikan dan Kebudayaan, Satpol PP, dan SMA/MA/SMK seKabupaten Tegal. Oleh karena itu perlu adanya persiapan yang matang. Selain itu, koordinasi yang dilakukan juga bertujuan sebagai evaluasi atas kegiatan yang dilakukan sebelumnya. Kami telah melakukan beberapa kali koordinasi, baik melalui rapat panitia kecil sampai rapat seluruh panitia serta pihak lain yang terlibat. Koordinasi terutama dilakukan ketika mendekati pelaksanaan seleksi Duta Lingkungan Hidup.

Untuk meningkatkan kompetensi yang berkaitan dengan pengelolaan web, kami juga telah melakukan pelatihan pengelolaan web kepada seluruh coordinator bidang di Dinas Lingkungan Hidup Kabupaten Tegal. Kegiatan pelatihan ini bertujuan agar setiap kali DLH melalukan kegiatan dapat segera diketahui oleh masyarakat luas. Kegiatan pemilihan Duta Lingkungan Hidup Kabupaten Tegal diikuti oleh 40 peserta putra dan 40 peserta putri dari SMA/MA/SMK se-Kabupaten Tegal. Kegiatan ini telah dilaksanakan dalam 3 Tahap.

\section{a. Seleksi Tahap I}

Seleksi Tahap I dilaksanakan tanggal 2 April 2017 dan merupakan seleksi awal yang diberikan kepada seluruh peserta pendaftar. Seleksi ini berupa tes tertulis dengan bentuk soal objektif. Hasil dari seleksi Tahap I akan diambil 15 besar peserta putra dan 15 besar peserta putri yang akan melanjutkan ke seleksi tahap II. Pengumuman 15 besar putra dan dapat dilihat di alamat www.dlh.tegalkab.go.id.

\section{b. Seleksi Tahap II}

Peserta yang lolos seleksi tahap I selanjutkan menghadapi seleksi tahap II yang dilaksanakan tanggal 9 April 2017. Seleksi ini diawali dengan kegiatan field trip ke bekas lokasi penambangan kapur Danau Beko di Kecamatan Margasari, Kabupaten Tegal. Di sana peserta dipersilahkan untuk melihat apa saja yang ada di sekitar Danau Beko sebagai bahan kajian yang akan ditulis oleh masing-masing peserta. Setelah melakukan perjalanan, peserta diajak kembali ke DLH Kab. Tegal, kemudian membuat tulisan yang berkaitan dengan hasil perjalanan yang dilakukan. Tulisan yang dibuat peserta meliputi identifikasi masalah, analisis masalah, dan alternatif solusi. Hasil tulisan peserta pada seleksi Tahap II dinilai oleh 3 juri dengan 5 kriteria penilaian yaitu kedalaman identifikasi masalah, kedalaman analisis, alternative solusi yang sesuai, tata bahsa, dan tata tulis. Peserta yang lolos seleksi Tahap II diambil dari $60 \%$ nilai tahap I dan $40 \%$ nilai Tahap II. Pengumuman dilakukan setelah pelaksanaan Kampanye Go Green.

\section{c. Seleksi Tahap III}

Seleksi Tahap III dilaksanakan pada tanggal 23 April 2017 di Pendopo Amangkurat Kabupaten Tegal. Kegiatan ini diawali dengan pelaksanaan kampanye Go Green yang diikuti oleh seluruh peserta dengan mengenakan pakaian yang dibuat dari daur ulang limbah padat. Sebelum dilakukan seleksi tahap III diumumkan 5 peserta putra dan 5 peserrta putrid yang lolos tahap II. Selanjutnya 1 peserta ini akan mendapatkan pertanyaan yang diambil langsung oleh peserta secara acak dan dijawab langsung oleh peserta secara lisan di hadapan audience. Penilaian hasil seleksi Tahap III diambil dari 60\% rata2 nilai Tahap I dan II serta $40 \%$ nilai tahap III. 

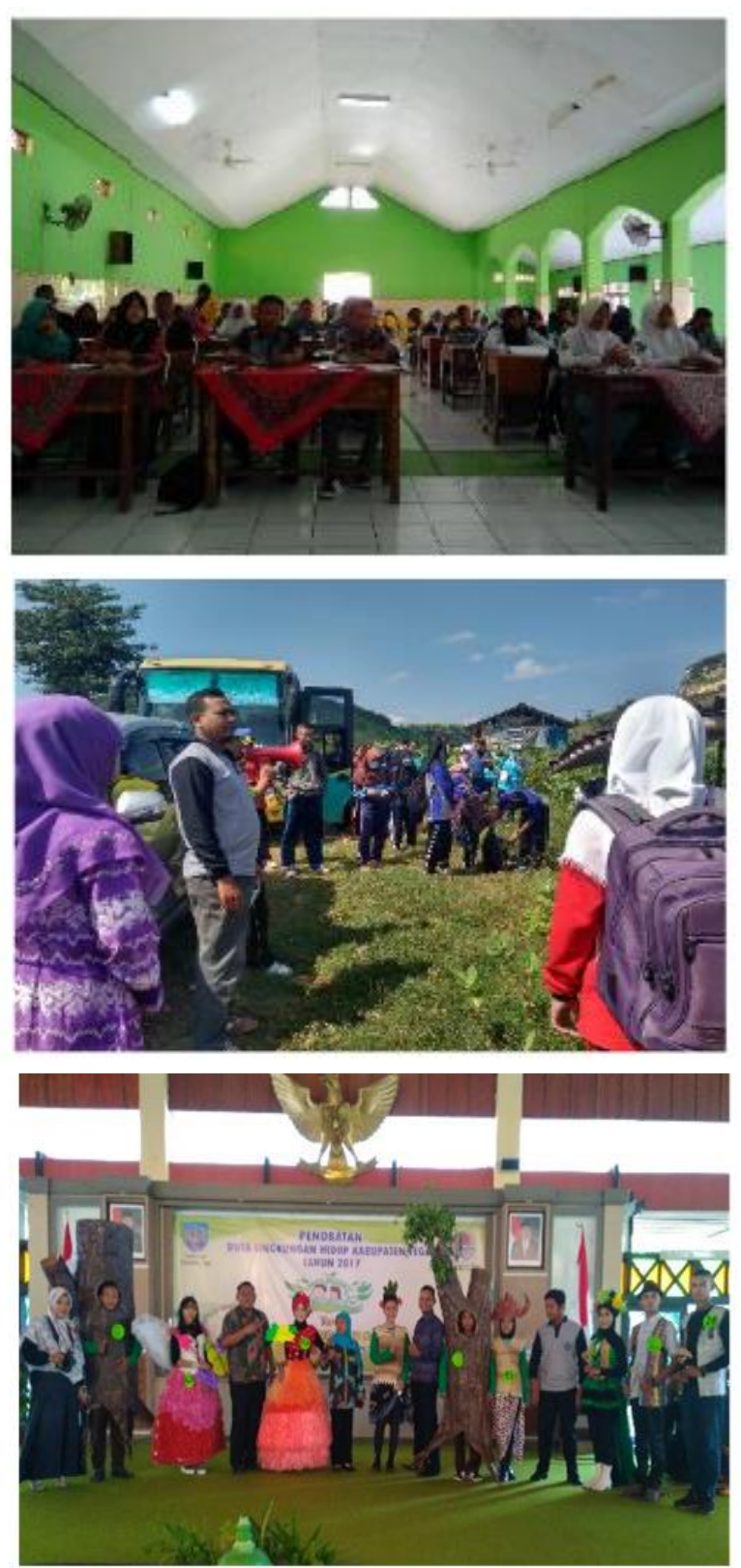

Gambar 1. Dokumentasi Pelaksanaan Kegiatan Duta Lingkungan Kab. Tegal

Kegiatan kampanye Go Green dilaksanakan tanggal 23 April 2017 mulai pukul 07.30 WIB. Peserta kampanye ini adalah seluruh peserta Duta Lingkungan Hidup, mahasiswa Pendidikan IPA UPS Tegal, dan pihak DLH Kabupaten Tegal. Kegiatan kampanye diisi dengan berjalan kaki mulai dari Gedung Rakyat Slawi sampai Pendopo Amangkurat Kabupaten Tegal. Peserta Duta Lingkungan Hidup dalam kampanye ini diwajibkan mengenakan kostum bertemakan lingkungan hidup yang dibuat menggunakan berbagai jenis limbah padat. Selain berjalan kaki, peserta kampanya Go Green juga membagikan sticker yang berisi pesan-pesan bertema lingkungan hidup dengan tujuan mengingatkan warga masyarakat akan pentingnya menjaga lingkungan dari segala bentuk kerusakan.

\section{KESIMPULAN}

Berdasarkan seluruh kegiatan IbM dapat disimpulkan bahwa kegiatan Duta Lingkungan Hidup terbukti menjadi kegiatan positif dalam upaya memberikan Pendidikan Lingkungan Hidup khususnya di kalangan pelajar yang nantinya akan disosialisasikan di kalangan mayarakat umum. Pendidikan Lingkungan Hidup yang diberikan melalui kegiatan ini sudah meliputi tiga aspek yaitu aspek kognitif, afektif, dan psikomotorik.

\section{DAFTAR PUSTAKA}

Amini, R. dan Munandar A. 2010. Pengaruh Model Pembelajaran Pendidikan Lingkungan Berbasis Outdoor Terhadap Penguasaan Konsep Pendidikan Lingkungan Calon Guru Sekolah Dasar. Jurnal Penelitian Pendidikan 11(1): 2-4.

Braus, J. A., and Wood, D. 1994, Environmental Education in the Schools: Creating a Program that Works. North American Association for Environmental Education in conjunction with the ERIC Clearinghouse for Science, Mathematics, and Environmental Education. Ohio: The Ohio State University.

Kantor Lingkungan Hidup Kabupaten Brebes. 2008. Status Lingkungan Hidup Daerah Kabupaten Brebes. Pemerintah Kabupaten Brebes - Kantor Lingkungan Hidup Brebes.

North American Association for Environmental Education. 2001. Using EnvironmentBased Education to Advance Learning Skills and Character Development. A Report, Annotated Bibliography, and Research. Washington: NEE \& Training Foundatio.

Sangkala. 2007. Knowledge Management: Suatu Pengantar Memahami Bagaimana Organisasi Mengelola Pengetahuan Sehingga Menjadi Organisasi yang Unggul. Jakarta. PT. Rajagrafindo Persada.

Sari, G. A. 2011. Analisis Mengenai Dampak Lingkungan Serta Upaya Penegakan Hukum Lingkungan Dalam Perspektif Yuridis Normatif. Jurnal Berkala Universitas Kediri Edisi Oktober 2010Januari 2011. 
56 Jurnal Pangabdhi 